\title{
БИОЛОГИЧЕСКАЯ ЗАЩИТА ЯБОЛНИ ОТ ЗЕЛЕНОЙ ЯБЛОННОЙ ТЛИ В УСЛОВИЯХ ЗАПОДНОЙ ЛЕСОСТЕПИ УКРАИНИ
}

\author{
Гунчак $М$. \\ Черновицкий филиал ГУ “Институт охраны почв”, Украинская научно- \\ исследовательская станция карантина растений ИЗР НААН; \\ email: gunchak00@ukr.net \\ Соломийчук $M$.
}

Украинская научно-исследовательская станщия карантина растений ИЗР НААН email: ukrndskr.zam@gmail.com

\begin{abstract}
The effectiveness of biological preparations for the protection of apple orchard from green apple aphids was studied in comparison with a chemical standard. It has been established that preparations of biological origin Actofit, c.e .; Coloradocid, p. against green apple aphid showed high efficiency of action - from 64.7 to $90.9 \%$. In addition, the high efficiency (67.4-75.0\%) of action and a synergetic effect was shown by a mixture of biological products Coloradocid, p. and Gaubsin, p.
\end{abstract}

Key words: apple tree, plant protection, aphids, biological preparations.

\section{Введение}

Проблемы получения экологически чистой плодовой продукции и загрязнения окружающей среды выдвигают необходимость разработки экологически безопасной системы защиты растений, которая в основном будет базироваться на преимущественном использовании биологических средств защиты. Это даст возможность стабилизировать экологическое равновесие в садовом агробиоценозе и оптимизировать объемы применения химических средств, для сохранения полезных видов и минимального негативного влияния на окружающую среду. Применение биологических препаратов имеет ряд преимуществ: избирательность действия и безопасность для энтомофагов и насекомых-опылителей; малую вероятность возникновения резистентности у насекомых к микроорганизмам; безопасность для человека и теплокровных животных; отсутствие влияния на вкусовые качества урожая; короткий срок ожидания, возможность применения в разные фазы вегетации растений; отсутствие угрозы накопления токсичных веществ в урожае, почве и окружающей среде [1-4].

Известно, что плодовым насаждениям яблони значительный ущерб наносят около 180 видов вредителей, для которых характерны большое разнообразие видового состава, различные способы жизни и повреждения, которые они наносят. В перечень вредителей яблони также включается и довольно значительное количество подряда тлей (Aphidinae), которые больше всего ее повреждают. Но наиболее распространенной в садовых агроценозах Западной Лесостепи Украины является зеленая яблоневая тля (Aphis pomi Deg.), личинки и имаго высасывающие сок из почек, последние в свою очередь отекают и распускаются; заселяют нижнюю сторону листьев, зеленые побеги, иногда завязи. Поврежденные листья скручиваются и отмирают. Побеги задерживаются в росте и искривляются. На сильно поврежденных деревьях плоды мельчают, на них часто растрескивается кожица [5-6].

Анализ источников литературы [1-9] свидетельствует - вопрос биологической защиты от зеленой яблонной тли в Западной Лесостепи Украины недостаточно изучен. Поэтому, дальнейшее расширение и углубление исследований по данному вопросу даст возможность адаптировать элементы биологической защиты от фитофага к условиям Западной Лесостепи Украины. 
Цель исследований заключалась в экологизации системы защиты яблоневого сада от зеленой яблонной тли с применением биологических препаратов. Задачей исследований было изучение действия биопрепаратов и определение их эффективности на численность зеленой яблонной тли (Aphis pomi Deg.).

\section{Материалы и методы}

Объектом исследований служил яблонный сад УкрНИСКР ИЗР НААН (с. Бояны, Черновицкая обл., Украина). Опыты проводились в посадках яблони 2005 года сорта Айдаред на подвое М-106. Почва опытного участка - чернозем оподзоленный, схема посадки: 4 х 2,5 м. Система содержания почвы - под многолетними травами. Фитосанитарный мониторинг проводили по общепринятым методикам [7]. Опрыскивание деревьев проводили в 2016-2019 гг. в фенофазы «розовый бутон», «формирование плодов», «рост плодов» (плод размером лещины) в сухую, солнечную погоду при температуре воздуха $18-22^{\circ} \mathrm{C}$.

Эффективность действия препаратов определяли через 2 и 7 суток по формуле Гендерсона и Тилтона [8]:

$$
E=(1-(B * a / A * b)) * 100 \text {; }
$$

где $\mathrm{E}$ - эффективность препарата в процентах снижения численности вредителя;

А - количество живых особей на опытном участке до обработки;

В - количество живых особей на опытном участке после обработки;

a - количество живых особей в контроле до обработки;

в - количество живых особей в контроле после обработки.

\section{Результаты и обсуждения}

Для защиты яблоневого сада применяли биопрепараты: Актофит, к.э. с нормой расхода 2,0 л/га (инсекто-акарицид), действующим веществом -комплексом природных авермектинов, продуцируемых полезным почвенным грибком Streptomyces avermitilis (Аверсектин С); Колорадоцид, п. с нормой расхода 3,0 кг/га (биоинсектицид), действующим веществом которого являются споры $\Delta$ - эндотоксина, $\beta$ - экзотоксина Bacillus thuringiensis ssp. thuringiensis (титр жизнеспособных клеток не менее 7 млрд. КУЕ/г); смесь Колорадоцида, п. (3,0 кг/га) с Гаубсином, с. (10,0 л/га), действующим веществом которого являются два штамма B-111 та В-306 бактерий Pseudomonas aureofaciens $\left(5 \times 10^{9}\right.$ КУЕ/мл). В качестве эталона был использован инсектицид химического происхождения Калипсо 480 SC, к.c. с нормой расхода 0,3 л/га, действующим веществом которого является тиаклоприд. Результаты исследований влияния препаратов биологического происхождения на зеленую яблоневую тлю приведены в таблице 1.

Исследованиями установлена эффективность препарата Актофит, к.э. с нормой расхода 2,0 л/га в 2016-2019 гг. в фенофазу «розовый бутон» через двое суток после обработки была самой высокой среди исследуемых препаратов $-57,5 \%$, а через 7 суток - 84,5\%. Начальная эффективность опрыскивания, проведенного на фазе «формирование плодов» составила $68,8 \%$, а эффективность биологического препарата через 7 суток составляла $87,1 \%$. Эффективность препарата на фазе «рост плодов» через 2 суток составила $69,0 \%$, а через 7 суток - 90,9\%, что свидетельствует о более высоком действии препарата на уменьшение плотности популяции зеленой яблонной тли с повышением температуры. 
Таблица 1

Эффективность инсектицидов биологического происхождения против зеленой яблонной тли, 2016-2019 гг.

\begin{tabular}{|c|c|c|c|c|c|c|c|}
\hline \multirow{2}{*}{$\begin{array}{c}\text { Вариант, норма } \\
\text { внесения }\end{array}$} & \multirow{2}{*}{$\begin{array}{c}\text { * Крат- } \\
\text { ность } \\
\text { обработ- } \\
\text { ки }\end{array}$} & \multicolumn{3}{|c|}{$\begin{array}{l}\text { Численность, экз./10 лист. } \\
\text { (среднее по повторностях) }\end{array}$} & \multicolumn{2}{|c|}{$\begin{array}{c}\text { Эффективность, } \\
\%\end{array}$} & \multirow{2}{*}{$\begin{array}{c}\text { Урожай- } \\
\text { ность, } \\
\text { т/га }\end{array}$} \\
\hline & & $\begin{array}{l}\text { до обра- } \\
\text { ботки }\end{array}$ & $\begin{array}{l}\text { через } \\
2 \text { oе } \\
\text { суток }\end{array}$ & $\begin{array}{c}\text { через } \\
7 \\
\text { суток }\end{array}$ & $\begin{array}{l}\text { через } \\
2 \text { oе } \\
\text { суток }\end{array}$ & $\begin{array}{c}\text { через } \\
7 \\
\text { суток }\end{array}$ & \\
\hline \multirow{3}{*}{$\begin{array}{l}\text { Контроль } \\
\text { (вода) }\end{array}$} & 1 & 272 & 293 & 335 & - & - & \multirow{3}{*}{16,7} \\
\hline & 2 & 311 & 325 & 350 & - & - & \\
\hline & 3 & 574 & 597 & 620 & - & - & \\
\hline \multirow{3}{*}{$\begin{array}{c}\text { Контроль } \\
\text { химический: } \\
\text { Калипсо } 480 \\
\mathrm{SC}, \text { к.с. }(0,3 \\
\text { л/га) }\end{array}$} & 1 & 231 & 23 & 10 & 90,8 & 96,5 & \multirow{3}{*}{17,6} \\
\hline & 2 & 272 & 26 & 12 & 90,8 & 96,1 & \\
\hline & 3 & 375 & 30 & 8 & 92,4 & 98,0 & \\
\hline \multirow{3}{*}{$\begin{array}{l}\text { Актофит, к.е. } \\
(0,6 \text { л/га) }\end{array}$} & 1 & 262 & 120 & 50 & 57,5 & 84,5 & \multirow{3}{*}{17,5} \\
\hline & 2 & 275 & 90 & 40 & 68,8 & 87,1 & \\
\hline & 3 & 385 & 125 & 38 & 69,0 & 90,9 & \\
\hline \multirow{3}{*}{$\begin{array}{l}\text { Колорадоцид, } \\
\text { п. (3,0 кг/га) }\end{array}$} & 1 & 241 & 152 & 105 & 41,6 & 64,7 & \multirow{3}{*}{17,3} \\
\hline & 2 & 282 & 155 & 93 & 47,2 & 70,6 & \\
\hline & 3 & 394 & 210 & 130 & 48,6 & 69,4 & \\
\hline \multirow{3}{*}{$\begin{array}{c}\text { Колорадоцид, } \\
\text { п. (3,0 кг/га) } \\
+ \text { Гаубсин, с. } \\
\text { (10 л/га) }\end{array}$} & 1 & 211 & 115 & 85 & 49,5 & 67,4 & \multirow{3}{*}{17,5} \\
\hline & 2 & 285 & 150 & 90 & 49,8 & 72,0 & \\
\hline & 3 & 405 & 220 & 110 & 48,1 & 75,0 & \\
\hline $\mathrm{HBP}_{05}$ & & 5,29 & 4,75 & 1,52 & & & 0,4 \\
\hline
\end{tabular}

* Обработки проводились на следующих фенофазах: 1 - «розовый бутон», 2 «формирование плодов», 3 - «рост плодов».

Эффективность биопрепарата Колорадоцид, п. (3,0 кг/га) через двое суток после опрыскиваний в годы исследований на фенофазе «розовый бутон» в среднем составляла $41,6 \%$, а через 7 дней - 64,7\%. Начальная эффективность следующих опрыскиваний составила $47,2 \%$ и 48,6\%, а эффективность биологического препарата через 7 суток составляла соответственно 70,6\% и 69,4\%.

Опрыскивание смесью препаратов Колорадоцид, п. (3 кг/га) и Гаубсин (10 л/га) позволило получить синергетический эффект, так - как эффективность проведенных мероприятий на фенофазах «розовый бутон» и «формирование плодов» через двое суток составляла 49,5\% и 49,8\% а через 7 дней - 67,4\% и 72,0\%, что на 1,4-2,7\% больше, чем при использовании Колорадоцида, п. Эффективность опрыскивания, проведенного в период роста плодов через двое суток, составляла 48,1\%, а через 7 дней $-75,0 \%$.

Применение инсектицида Калипсо 480 SC, взятого за эталон, позволило значительно ограничить численность вредителей. Техническая эффективность его действия против зеленой яблонной тли в 2016-2019 гг. в среднем, через 2 суток составляла 90,8\%, 90,8\% и 92,4\%. Эффективность его действия через 7 суток составляла $96,5 \%, 96,1 \%$ и $98,0 \%$. 
Итак, самую высокую начальную эффективность среди биологических препаратов показал препарат Актофит, к.э. в норме 2,0 л/га при опрыскивании во время роста плодов - 69,0\%. Самую высокую техническую эффективность показал препарат Актофит, к.э. $-90,9 \%$.

\section{Выводы}

1. При применении биопрепаратов Актарофит, к.э., Колорадоцид, п. и смеси Колорадоцида, п. с Гаубсином, с. в агроценозе яблоневого сада Украинский научноисследовательской станции карантина растений Института защиты растений Национальной академии аграрных наук Украины обнаружилось высокое энтомопатогенное действие, сдерживавшее распространение зеленой яблонной тли (Aphis pomi Deg.).

2. Для экологизации технологии защиты яблоневого сада от вредителей целесообразно- ограничение препаратов химического происхождения на фенофазе «розовый бутон», «формирование плодов», «рост плодов» (плод размером с лещину) и в соответствующих погодных условиях применения биопрепаратов Актарофит, к.э. (2,0 л/га), Колорадоцид, п. (3,0 кг/га), и смеси Колорадоцида, п. (3,0 кг/га) с Гаубсином, с. (10,0 л/га), показали высокое действие на фитофаги.

3. Установлено, что препараты биологического происхождения Актофит, к.э.; Колорадоцид, п. против зеленой яблонной тли показали эффективность действия от 64,7 до 90,9\%. Кроме того высокую эффективность (67,4-75,0\%) показала смесь биопрепаратов Колорадоцид, п. и Гаубсин, с.

\section{Библиография}

1. Бровдій В.М., Гулий В.В., Федоренко В.П. Біологічний захист рослин. Навчальний посібник. Київ: Світ, 2003. 352 с.

2. Дядечко М.П., Падій М.М., Шелестова В.С. та ін. Біологічний захист рослин. Біла Церква, 2001. 312 с.

3. Рябчинская Т.А., Харченко Г.Л. Экологизация защиты яблони от вредних организмов. Москва: ФГНУ «Росинформагротех», 2006. 188 с.

4. Гунчак М. В. Экологизация системы защити яблони от вредных организмов в условиях Юго-Западного региона Украины. Информаџионный бюллетень ВПРС МОББ. 2017. № 52. С. 94-99.

5. Довідник із захисту рослин; за ред. Лісового М.П. Київ: Урожай, 1999. 744 с.

6. Біологічний метод захисту яблуні від шкідливих організмів / М. В. Гунчак, Л. Л. Гаврилюк, М. П. Соломійчук, А. М. Скорейко. Чернівці: ФОП Варвус В. В., 2018. $18 \mathrm{c}$.

7. Облік шкідників і хвороб сільськогосподарських культур; під ред. В.П. Омелюти. Київ: Урожай, 1986. 293 с.

8. Трибель С.О., Сігарьова Д.Д., Секун М.П. та ін. Методики випробування і застосування пестицидів. Київ: Світ, 2001. 448 с. 